\section{THAI IMPERSONAL PRONOUNS AND LANGUAGE POWER ${ }^{1}$}

\section{Kitima Indrambarya ${ }^{2}$}

บทคัดย่อ

ประธานอบุรุษหมายถึงประธานที่ไม่มีความหมาย ในตัวเอง งานวิจัยในอดีต (Indambarya 1996, 2011

Phimsawat 2011) ได้กล่าวถึงคำสรรพนามอบุรุษ มัน และ เขา ที่ทำหน้าที่เป็นประธานของคำกริยาไร้ ประธาน อย่างไรก็ตามยังมีคำสรรพนามอบุรุษ ท่าน ที่ยังไม่ได้กล่าวถึง บทความวิจัยนี้มีวัตถุประสงค์ใน การศึกษาความสัมพันธ์ระหว่างประธานอบุรุษทั้ง สามคำที่ปรากฏในทำเนียบภาษาต่างๆ กับระยะห่าง ระหว่างผู้พูดและอำนาจของภาษา ผลการวิจัยพบว่า สรรพนามอบุรุษ ท่าน และ เขา ใช้ในวงจำกัด สรรพนามอบุรุษ ท่าน สะท้อนระยะห่างระหว่างผู้ พูดและผู้ฟังมากที่สุด และยังสามารถสะท้อนอำนาจ สูงสุดด้วย ในขณะที่ผู้พูดใช้ ท่าน และ เขา เพื่อ สร้างช่องว่างระหว่างผู้พูดและผู้ฟังในการชักจูงให้ ผู้ฟังกระทำตามความประสงค์ ผู้พูดจะใช้สรรพนาม อบุรุษ มัน ในการลดช่องว่างและดึงผู้พูดให้ใกล้ชิด กับผู้ฟังมากขึ้น

\footnotetext{
' สรรพนามอบุรุษกับอำนาจของภาษา

${ }^{2}$ (กิติมา อินทรัมพรรย์) Associate Professor, Department of Linguistics, Faculty of Humanities, Kasetsart University
}

\section{ABSTRACT}

Impersonal subjects are subjects unspecified for their reference. While previous analyses identified man 'it' and kháw as non-referential subject in Thai co-occurring with impersonal verbs (Indrambarya 1996, 2011, Phimsawat 2011), there exists the use of third person pronoun thân 'they' as an impersonal pronoun. This paper aims at investigating how the three impersonal subjects in Thai exhibit the distance between speakers and reflect the language power inherited in different language registers.

The result shows that the use of the impersonal pronouns thân 'they' and kha'w 'they' are much more limited than man 'it'. The pronoun thân 'they' is the most distant and the most powerful among the three impersonal pronouns. While the impersonal pronouns thân 'they' and kha'w 'they' covey the gaps between users leading addressees to follow what is to be done, the impersonal pronoun man 'it' brings speakers closer to addressees for more consolidation.

\section{Introduction}

Most pronouns are personal and unmarked. Impersonal pronouns are marked and less common. Many languages have both personal and impersonal pronoun counterparts. Some make use of third person pronouns as impersonals, such as English dummy it and French il 'it'. Indrambarya (1996, 2011) identified the pronoun man 'it' as an impersonal subject in Thai. The term 'impersonal subjects', or non-referential subjects are identified in lexicase dependency grammar as subjects which 
have no reference, as in (1) where man 'it' does not have any reference.

(1) wan níi man rósn cay day this it hot much 'Today it is so warm.'

(daily conversation)

Besides man 'it', two impersonal subjects kháw 'they' and thân 'they' are also found. The presence of the impersonal pronouns kháw 'they' and thân 'they' in (2) and (3) are not as common as the impersonal pronoun man 'it' in (1).

(2) kháw $^{3}$ lï kan wâa they rumor together that bâan níi mii phĭi house this have ghost 'It is rumored that this house is haunted.'

(3) námmon thân wâa khlăy holy water they say have strong magical power

'It is said that holy water has strong magical power.'

This paper aims at investigating how these impersonal subjects appear in different language registers and differ in their ability to express distance and language power.

3 kháw 'he, she', with the high tone mark, is a common variant of the written standard form $\boldsymbol{k h a ̆ w}$, with the rising tone mark. The two forms can be used interchangeably. While $\boldsymbol{k h a} \boldsymbol{w}$ is commonly found in daily speech, $\boldsymbol{k h a ̆ w}$ is found in formal and emphatic speech. This paper captures how people use language in daily activities and hence kháw is used throughout the paper. Likewise, țán 'I' can be used interchangeably with țăn 'I'.

\section{Data Collection}

In this study, data consisting of 201,911 words were collected from both spoken and written language from five registers, namely, everyday language, academic language, media language, political language and legal language. Written language includes academic journal and newspapers, magazine advertisements, and legal documents. Spoken language data were drawn from daily conversations as well as those found on TV talk shows, TV and radio, news reports, and political speeches. Even though talk shows could be viewed as media language, conversations on topics in focus discussed by guests in these programs such as "the VIP Program" are unlikely prepared and represent daily language use. Only news reports and advertisements are classified as media language in this study. Different types of data collection can be summarized in the following table.

Table 1: Types of data collection

\begin{tabular}{|c|c|c|}
\hline & $\begin{array}{c}\text { Spoken } \\
\text { Language }\end{array}$ & $\begin{array}{c}\text { Written } \\
\text { Language }\end{array}$ \\
\hline $\begin{array}{l}\text { Everyday } \\
\text { language }\end{array}$ & $\begin{array}{l}\text { conversation in } \\
\mathrm{TV} \text { talk shows } \\
\text { daily } \\
\text { conversation }\end{array}$ & - \\
\hline $\begin{array}{l}\text { Academic } \\
\text { Language }\end{array}$ & - & $\begin{array}{l}\text { academic } \\
\text { journals }\end{array}$ \\
\hline $\begin{array}{c}\text { Media } \\
\text { Language }\end{array}$ & $\begin{array}{l}\text { TV news } \\
\text { radio news }\end{array}$ & $\begin{array}{l}\text { newspapers, } \\
\text { magazine } \\
\text { advertisement }\end{array}$ \\
\hline $\begin{array}{c}\text { Political } \\
\text { Language }\end{array}$ & political speech & - \\
\hline $\begin{array}{c}\text { Legal } \\
\text { Language }\end{array}$ & - & legal document \\
\hline
\end{tabular}




\section{Analysis}

\section{Deictic vs. Anaphoric pronouns}

Deictic and anaphoric pronouns are related terminologies which need to be clarified here. Deictic pronouns, according to Mathews (1997:9), refer to those pronouns whose references are determined by the context of speakers and addressees. Person deixis such as $I$, which refers to the speaker in I live here, is one of the five common types of deixis (person deixis, spatial deixis, social deixis, temporal deixis, and discourse deixis). Anaphoric pronouns, on the other hand, are those pronouns whose antecedents can be found within the text or utterance. While the first person pronoun phom 'I (male)' and $k_{h a ́ w_{1}}$ 'I' in (4) and the second person pronoun thân $n_{l}$ 'you' in (5) are deictic pronouns, the third person pronouns thân $n_{2}$ 'he, she' in (6) and kháw 2 'he, she' in (7) and man 'it' in (8) are anaphoric.

\section{(4) phǒm / kháw 1 mây ȟ̌w} I he not hungry 'I am not hungry.'

(5) $\boldsymbol{t h a ̂ n}_{1}$ cà? ráp t ţaa you will receive tea ræ̈ kaafeE dii khá? or coffee good Prt 'Would you like tea or coffee?'

(6) khunyॅ̆ yùu khâaynay // Lady stay inside thân ${ }_{2}$ ros Ø yùu he/she wait PROG 'The lady is inside. She is waiting (for you).'

$$
\begin{aligned}
& \text { (7) suthii phôn klàp } \\
& \text { Suthee just return } \\
& \text { càak tàancaywàt // } \\
& \text { from upcountry } \\
& \text { kháw }{ }_{2} \text { khâw noon lécw } \\
& \text { he/she enter sleep already } \\
& \text { 'Suthi has just returned from } \\
& \text { upcountry. He has gone to bed.' }
\end{aligned}
$$
(8) yàa km phónlamay lăy
Do not eat fruit after
Paahăan prô? man phỏ
food because it swollen
nay thósy
in abdomen

'Do not eat fruit after meals because it swells in your stomach.'

The first person pronoun kháw ${ }_{1}$ 'I' in (4) and the third person kháw 'he, she' in (7) are used informally. The pronoun kháw 'I' in (4) refers to the speaker and hence is a deictic pronoun, while kháw 'he, she' in (7) refers to Suthii and so is anaphoric. In (5), the second person pronoun thân ${ }_{1}$ 'you' refers to the addressee and so is deictic. The pronoun thân ${ }_{2}$ 'he, she' in (6), on the other hand, refers to khunyı̆n 'the lady' in the sentence and hence is anaphoric. Similarly, the third person pronoun man 'it' in (8) refers back to its antecedent phónlamay 'fruit' in the sentence and is anaphoric.

\section{Personal vs. Impersonal Pronouns}

Pronouns in Thai are mostly personal. All the pronouns mentioned in the previous section are personal. That is, they refer to persons or things and hence are referential. Within Lexicase Dependency Grammar, a personal verb is defined as having a referential subject carrying the feature 
[+rfrn] (reference) while impersonal verbs carry a non-referential subject with the feature [-rfrn] (Indrambarya 1996). The term 'impersonal' is created as a counterpart of the common 'personal' one. Phimsawat (2011:57) defines impersonal pronouns as referring to one or more unspecified persons without having any antecedents. Phimsawat (2011:59) further states that the English impersonal pronoun system can be classified into two types: generic and arbitrary. The English impersonal pronoun one is the only pure generic impersonal pronoun while you, we, and they have both generic and arbitrary readings. The impersonal pronoun one is called generic inclusive. That is, it includes both the speaker and the addressee and can be used interchangeably with you, as in (9).

(9) One/You has/have to pay more for organic products.

(Phimsawat 2011:59)

According to Phimsawat (2011:59), the English impersonal pronoun they can have two generic readings and four arbitrary readings based on Hofherr (2003 cited in Phimsawat 2011:60). The arbitrary impersonal pronoun they can be classified into four subtypes: specific existential, vague existential, inferred existential, and corporate reading. Phimsawat (2011:5961) offers examples of each type of impersonal they as follows.

\section{(10) a. They eat snails in France.}

(generic exclusive)

\section{b. They stole my car.} (generic quasi existential)

c. They are fixing your car now. (specific existential arbitrary)

d. They have found my dog. (vague existential arbitrary)

\author{
e. They have cleaned the public \\ toilet. \\ (inferred existential arbitrary) \\ f. They delivered the parcel \\ yesterday. \\ (corporate reading)
}

The impersonal pronoun they in (10a) carries the generic exclusive reading in excluding both speakers and addressees, maintaining the plural reading and cooccurring with the locative in France. In (10b), the impersonal pronoun they is quasi existential with the singular reading of 'someone' who stole my car. In (10c), the impersonal pronoun they is specific existential for being specified at a point in time and yet, they, in (10d), is vague existential in not specifying a point of time when 'someone has found my dog'. In (10e), the impersonal pronoun they is inferred existential since the cleanliness of the toilet infers that someone has cleaned it. And the impersonal pronoun they in (10f) is a corporate reading since the only designated group of people delivering the parcel is the mail carrier.

In Thai, Phimsawat (2011:67) found generic inclusive use of impersonal raw 'we', as in (11) and the use of impersonal kháw 'they' in both generic and arbitrary readings. She considers kháw 'they' to be a shortened form of phûakháw 'they'. (12) exemplifies the generic exclusive reading while (13) and (14) show vague existential arbitrary and a corporate reading, respectively.

(11) raw km cee nay dian
we eat vegetarian in month
tulaakhom
October
'We have vegetarian food in October.'
(Phimsawat 2011:66)


Like the English quasi-inclusive generic we, raw 'we' in (11) must be present to maintain its non-referential reading. In (12), kháw 'they' is an exclusive generic impersonal pronoun with the plural reading with an obligatory locative. Without the locative thîi mùubâan níi 'in this village', kháw in (12) can only have a referential reading.

\section{(12) thîi mùubâan níi kháw at village this they mây km nt́a kan ləəy not eat meat each other at all 'In this village, they don't eat meat at all.'}

(Phimsawat 2011:66)

Example (13) shows kháw 'they' as a vague existential since no specific time is given. Example (14) exemplifies the corporate reading in that the action of selling eggs is carried out by merchants and not other professionals.

\section{(13) kháw bj̀s wâa kruythêep they say that Bangkok náam cà? thûam water will flood 'They said that Bangkok would be hit by floods.'}

(Phimsawat 2011:67)

\section{(14) kháw khîn raakha khày Pìiklécw they raise price egg again 'They have raised egg prices again.'}

(Phimsawat 2011:67)

The present study defines impersonal pronouns as pronouns [+prnn] (pronoun) which could be human or non-human [ \pm humn] (human), having no antecedent [-ntcd] (antecedent), and having either no reference [-rfrn] (reference) or an unspecified reference [-spcf] (specified).

$$
\left[\begin{array}{c}
\text { Thai impersonal Pronoun } \\
\pm \text { humn } \\
\text {-ntcd } \\
{[\text {-rfrn] or [-spcf] }}
\end{array}\right]
$$

Three third person pronouns are found to have homophonous impersonal counterparts: $\operatorname{man}_{2}$ 'it', kháw $w_{3}$ 'they' and thân $_{3}$ 'they'. Unlike Phimsawat (2011) who considers kháw 'they' to be a shortened form of phuakkháw 'they', this study considers phuakkháw 'they' and $k h a$ w ' they' to be different words and only the latter form has an impersonal counterpart in Thai. Let us take a closer look at each of the three impersonal pronouns in Thai.

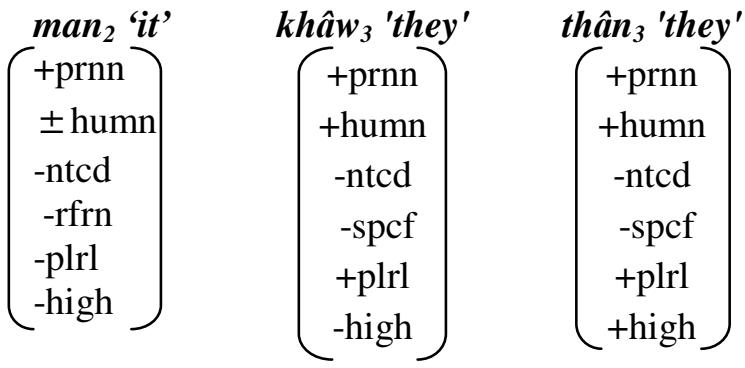

While the impersonal pronoun $\mathrm{man}_{2}$ 'it' could be human or non-human and nonreferential without any antecedents, the impersonal pronoun $k h a ̂ w_{3}$ 'they' and thân $_{3}$ 'they' are unspecified human with plurality and no antecedents. The difference between khâw $w_{3}$ 'they' and thân 'they' lies in the feature [ \pm high] (high rank). The impersonal pronoun khâw 'they' is of equal status and thus carries the feature [-high] while the impersonal pronoun $t h a n_{3}$ 'they' is higher in rank and thus [+high]. 
The impersonal pronoun man 'it' in (15) and (16) does not refer to anything, and hence is non-referential. Similar to the French impersonal pronoun on which appears in an informal usage, Thai pronoun $\mathrm{man}_{2}$ 'it' may occur with trueimpersonal verbs in colloquial usage, as shown in (15). The pronoun $\mathrm{man}_{2}$ 'it' cooccurs with the true-impersonal verb mii 'to exist' denoting existence. Thai trueimpersonal verbs carrying the feature [+mprs (impersonal), -psdo (pseudo)] refer to verbs which do not require the presence of a non-referential subject. Thus, the trueimpersonal existential verb mii in (15) can occur with or without the surrogate subject $m a_{2}$ 'it', but not kháw 3 nor thân

(15) $\boldsymbol{\sigma} / \boldsymbol{m a n}_{2}{ }^{*} \boldsymbol{k h a ́ w}_{3} / *$ thân $_{3}$ mây mii
it / they / they not $\begin{aligned} & \text { exist } \\ & \text { Nom }\end{aligned}$
-rfrn
panhăa ròk
problem Prt

'There is no problem.'

(daily conversation)

In (16), the true-impersonal verb $d$ ì 'to be late at night' denoting temporality may appear with or without a subject. The only possible subject to co-occur with $d \grave{\text { ik }}$ 'to be late at night' is the impersonal man $_{2}$ 'it'. As illustrated in (16), the presence of the first person pronoun tfán 'I' as well as that of the impersonal pronouns kháw 3 and thân ${ }_{3}$ would not be acceptable.

$\begin{array}{rll}\text { (16) kwàa } & \text { cà? thæ̆y bâan } \\ \text { more } & \text { will arrive house }\end{array}$

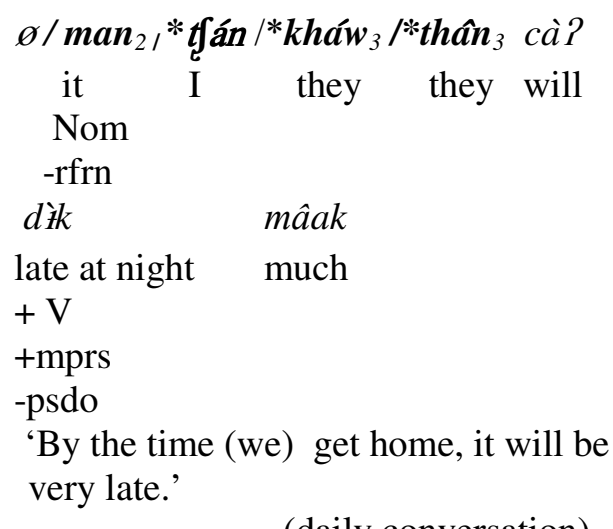

(daily conversation)

Example (17b) shows the presence of the impersonal pronoun $\mathrm{man}_{2}$ 'it' with the pseudo-impersonal verb khîkiat ${ }_{2}$ 'to be lazy'. Here, as proposed in Indrambarya (2011), man 'it' functions as an impersonal marker and is used to convert the personal verb khîkiat $_{1}$ in (17a) to an impersonal counterpart in (17b). The personal verb khîkiat $_{l}$ in (17a) co-occurs with personal subjects such as țán 'I' $k h a ́ w_{1}$ 'I', and kháw ${ }_{2}$ 'he or she' as permitted by the context. When a null subject is present, it refers back to țán 'I', $k h a ́ w_{1}$ 'I' and kháw $w_{2}$ 'he or she' within the context. The pseudo-impersonal verb khîkiat $_{2}$ requires the presence of the impersonal $\mathrm{man}_{2}$ 'it', and not any other impersonal subjects, as shown in (17b). The impersonal subject $\mathrm{man}_{2}$ 'it' alienates the speaker from his/her own self and makes him/her talk more freely as if he/she is someone else.

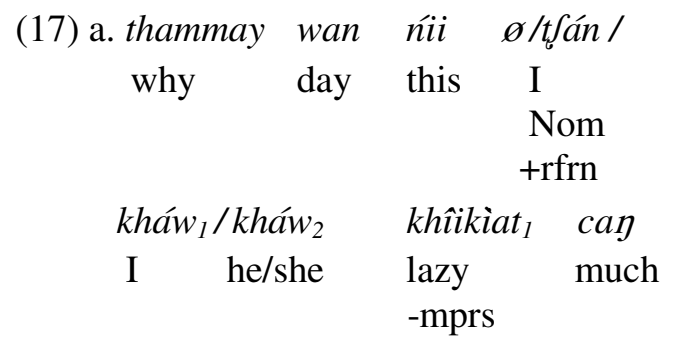


'Why am I so lazy today?'

'Why is he/she so lazy today?'

b. thammay wan nii $\boldsymbol{m a n}_{2 /}$ why day this it

Nom

-rfrn

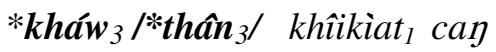

they they much
+ mprs
+ psdo

'Why am I so lazy today?'

Unlike the impersonal pronoun $\operatorname{man}_{2}$ 'it', the two impersonal pronouns kháw 3 'they' and $t h a n_{3}$ 'they' are more limited in usage. They refer to an unspecified group of people and carry the features [-spcf] (specified). In (18), the verb wâa 'to say' is an impersonal verb which requires the presence of an unspecified human impersonal subject. The only two possible impersonal subjects co-occurring with verbs denoting speech are kháw 3 'they' and thân ${ }_{3}$ 'they'. And yet, only the impersonal pronoun kháw 3 'they' sounds natural in the context of (18). It is not known to whom the pronoun kháw 3 'they' refers. This type of impersonal verb corresponds to Phimsawat's (2011) vague existential arbitrary kháw 'they' for the obscure point of time of the shop's reputation.

(18) $\boldsymbol{k h a ́ w}_{3} / * \boldsymbol{m a n}_{2} /$ ?thân 3 wâa they / it / they say Nom

+humn

-spcf

kuăytǐaw ráan níl Paròy noodle shop this delicious 'It is said that the noodles at this shop are delicious.'

(daily conversation)
Like the impersonal kháw ${ }_{3}$ 'they' in (18), the impersonal pronoun thân ${ }_{3}$ 'they' in (19) is unspecified for gender. It implies a certain number of elder persons, particularly those who are wise or respected. The presence of the impersonal pronoun $\mathrm{man}_{2}$ 'it' is not acceptable in (19). The impersonal pronoun thân $n_{3}$ 'they' is found to co-occur only with the impersonal verbs wâa 'to say' and hây 'to make, to cause'. The use of the impersonal pronoun thân 'they' in Thai, as in (19), would belong to the corporate reading arbitrary type of impersonal subject as classified in Phimsawat (2011:59-61) since the interpretation of $\operatorname{than}_{3}$ 'they' refers to wise people of the older times. Example (19) is also acceptable with the presence of the impersonal subject kháw 3 'they'. In this case, kháw 3 'they' refers to an unspecified group of people in general and falls into Phimsawat's (2011:59-61) category of vague existential arbitrary.

\section{(19) námmon khïn canpen holy water night full moon} thân $\boldsymbol{n}_{3} / \boldsymbol{k h a ́ w}_{3}$ / * $\boldsymbol{m a n}_{2}$ wâa they they it say
Nom
-spfc
khlăg
strong magical power
'It is said that holy water on a full
moon night has strong magical
power.' (daily conversation)

This section has exemplified three pairs of homophonous personal and impersonal counterparts of Thai pronouns. The next section will discuss how these impersonal pronouns behave in different language registers. 


\section{Impersonal pronouns in language registers}

This section discusses the occurrence of each impersonal pronoun in the five language registers, namely, everyday language, academic language, media language, political language and legal language. The following figure illustrates the occurrence of each impersonal pronoun in the five language registers. occurrence of 0.53 and 0.18 , respectively, within a text of 1,000 words. The impersonal pronoun man 'it' is not found in academic, legal or media language. Moreover, the other two impersonal pronouns are much less commonly used. The impersonal pronouns kháw $w_{3}$ 'they' and thân $n_{3}$ 'they' are found only in everyday language with 0.01 occurrence out of a text of 1,000 words. They are scarcely found in other language registers. The following subsection discusses how each impersonal pronoun behaves in each language register.

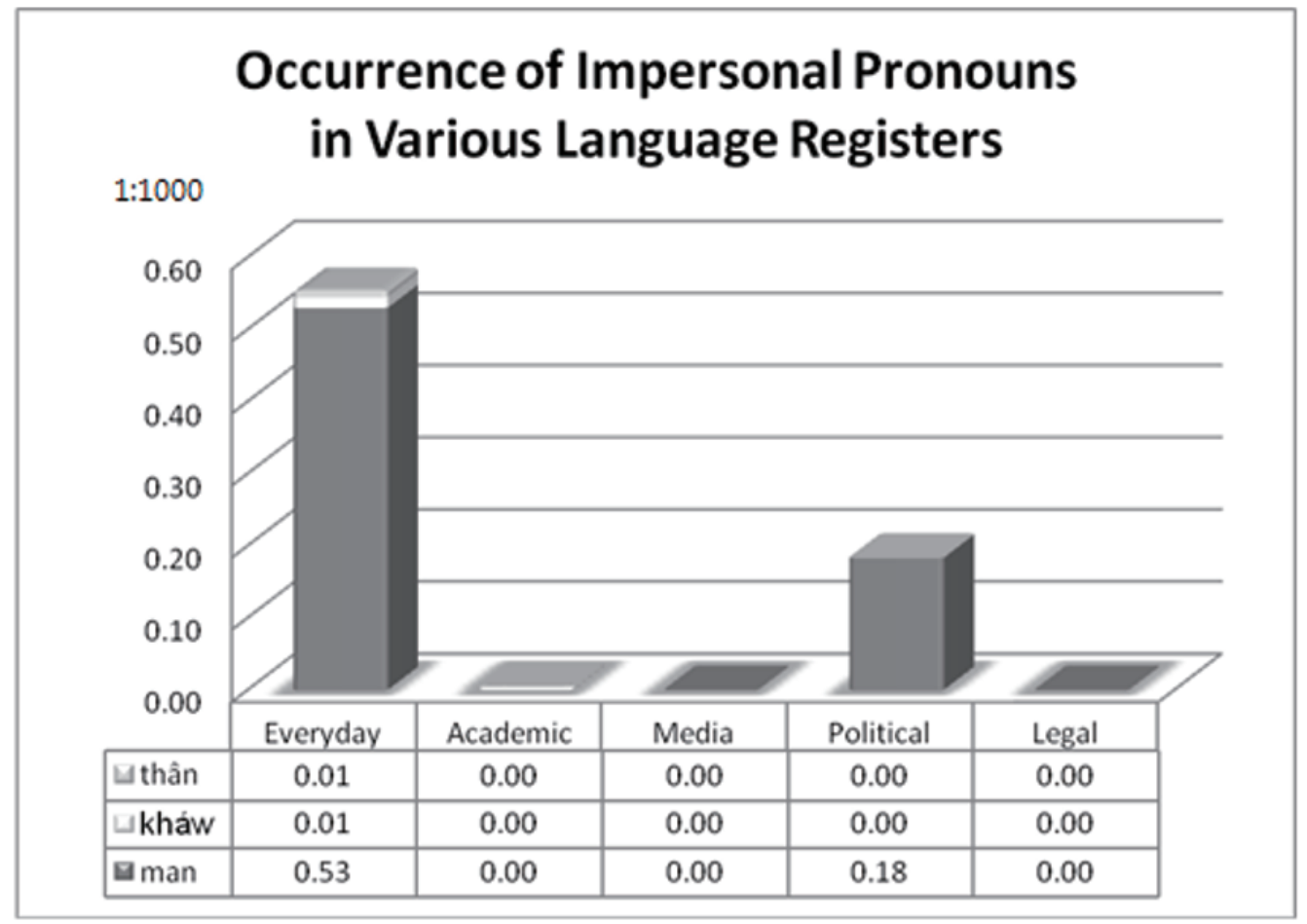

Figure 1: Occurrence of Impersonal Pronouns in Various Language Registers

Based on the data of 201,911 words, this study found 150 occurrences of impersonal pronouns $(0.74$ times out of 1,000 words). Obviously, the impersonal pronoun $\mathrm{man}_{2}$ 'it' is the most frequently used. It is found most in everyday language, followed by political language. That is, this pronoun is found at the

\section{Everyday Language}

Everyday language is informal spoken language used in everyday life. Impersonal subjects are found most in everyday language, especially the impersonal subject man 'it'. This section explores the 
occurrence of the three impersonal subjects in the language of everyday use.

The Impersonal Pronoun man $_{2}$ 'it'

The impersonal subject $\mathrm{man}_{2}$ 'it' may optionally co-occur with true-impersonal verbs or those without an overt nonreferential subject, such as kə̀at 'to happen' as in (20), and with pseudo-impersonal verbs, those which require the presence of the dummy subject man 'it', such as dìk 'late' as in (21a).

$$
\begin{array}{rllll}
\text { (20) } n \hat{i} i & \text { man }_{2} & \text { kà̀t } & \text { Paray } & \text { kht̂n } \\
\text { this } & \text { it } & \text { happen what up } \\
\text { Nom } & +\mathrm{V} & & \\
\text {-spcf } & + \text { mprs } & & \\
& & \text {-psdo } &
\end{array}
$$

'What has happened?'

(daily conversation)

In (20), the impersonal subject pronoun man 'it' co-occurs with the verb denoting existence kàst 'to happen' in informal or colloquial speech. As proposed by Indrambarya (2011), the impersonal pronoun man 'it', when co-occurring with the pseudo-impersonal verb láa $a_{2}$ to be exhausted', in (21a), is a marker for converting the personal verb láa $a_{1}$ 'to be exhausted' in (21b) into an impersonal one.

$\begin{array}{ccc}\text { (21) a. } \operatorname{man}_{2} & \text { láa } & \text { sùtsùt } \\ \text { it } & \text { exhaust } & \text { extremely } \\ \text { Nom } & \text { +mprs } & \\ \text {-rfrn } & \text { +psdo } & \\ \text { 'I feel absolutely exhausted.' }\end{array}$

\begin{tabular}{ccc} 
b. țán & láa & sùtsùt \\
I & exhaust & extremely \\
Nom & -mprs \\
+rfrn & \\
'I feel absolutely exhausted.' & \multicolumn{2}{c}{ (daily conversation) }
\end{tabular}

\section{The Impersonal Pronoun kháw 3 'they'}

The use of the impersonal pronoun kháw 'they' is found sparingly in daily language usage, as shown in (22). The impersonal pronoun kháw $w_{3}$ 'they' does not refer to any specific person and its reference cannot be retrieved from the text. It is unknown who $k h a ́ w_{3}$ 'they' actually is. The impersonal pronoun kháw $w_{3}$ 'they' is often found to cooccur with the impersonal verb wâa 'to say'.

$$
\begin{aligned}
& \text { (22) kháw wâa kan wâa } \\
& \text { they say together say } \\
& \text { Nom } \\
& \text {-rfrn }
\end{aligned}
$$

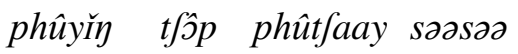

$$
\begin{aligned}
& \text { woman like man surrealistic } \\
& \text { 'It is said that women like } \\
& \text { 'surrealistic' men.' }
\end{aligned}
$$$$
\text { (daily conversation) }
$$

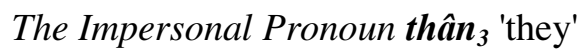

The impersonal pronoun thân $n_{3}$ 'they' is used sparingly and in quite limited contexts. It can be found in legends, as well as in traditional herbal medicine, mostly in everyday language. Here in example (23), the word thân 3 'they' originally referred to wise elders or the wise. Like the impersonal kháw $w_{3}$ 'they', this impersonal pronoun thân $n_{3}$ 'they' is unspecified both for gender and number. It is generally acceptable to interpret thân 'they' as the elderly and the wise of an earlier time.

(23) thân ${ }_{3}$ hây Paw tônmayarâap
they make take mimosa plant
Nom
-spcf
tônkrôpcakrawan maa láay
all purpose plant come wash




\begin{abstract}
náam saPàat hàn pen fŭy water clean chop be shred tàak hây hêy khûa fay sun-dry till dry roast fire hây sùk rin námyaa make fully cooked pour medicine ráprathan thecn náamţaa eat instead of tea

'It is said that after rinsing mimosa and the all-purpose plants with clean water, and then shredding, sun-drying and roasting them, one can drink the juice as a tea.'
\end{abstract}

(Traditional recipe for making herbal medicine for curing diabetes)

\section{Political Language}

Only the impersonal subject man 'it' is found in political language. The impersonal pronoun man $_{2}$ 'it' can co-occur with both true-impersonal verbs, as in (24), and pseudo-impersonal verbs, as in (25).

\begin{tabular}{llll} 
(24) man mây pen rîay dii \\
it & not be story good \\
Nom & \multicolumn{2}{c}{+ mprs } \\
-rfrn & -psdo \\
sǎmràp & prathêtțâat lé? \\
for & nation & and \\
prațațon loay & \\
people at all &
\end{tabular}

'It is neither good for the nation nor for the people.'

(political speech)

In political language, politicians tend to reach out to their audience and so the use of man 'it' with the true-impersonal verb pen 'to be' in (24) makes the sentence informal and easier for politicians to talk to supporters. Example (25) is an instance of the impersonal subject man 'it' cooccurring with a pseudo-impersonal verb ţaná? 'to win' to strengthen the unity of speaker and audience as members of the same group sharing a similar experience so that moving toward the same goal is simpler.

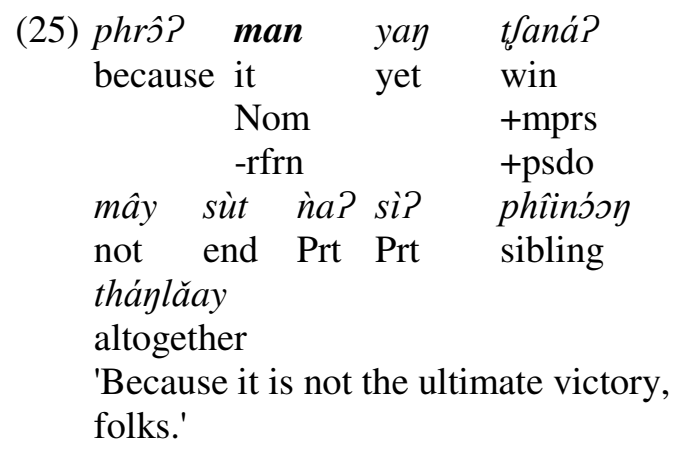

(political speech)

\section{Media Language}

No impersonal subject was found in news reports: newspapers, TV and radio news broadcasts, nor in any magazine advertisements. Note that the impersonal subject man 'it' can be found in the interview part of a news item but it is not counted as part of media language.

\section{Academic Language}

Academic language is the register which is formal and concise. Indrambarya (2014) found that academic language tends to use true-impersonal verbs, rather than pseudoimpersonal verbs. Impersonal subjects which co-occur with true-impersonal verbs illustrate informality and hence not expected in this language register. As expected, the impersonal subject man 'it' then was not found. However, this study found one instance of the impersonal subject kháw co-occurring with the trueimpersonal verb rîak 'to call' in a medical journal for the general public, as in (26). Here, it is an instance where the writer 
may be trying to express closeness with readers.

\section{(26) tamnèy kaankhûapkhum kaanbèy position control dividing sel kháw rîak proto Pojkhociin cell they call proto Oncogene -rfrn}

'The position of cell division control is called Proto Oncogene.'

(medical journal for the general public 2)

\section{Legal Language}

Even though legal language makes most frequent use of true-impersonal verbs such as hây 'to make, to cause', none of the impersonal subjects were found in legal language. This is because legal language is a formal language register. The presence of the impersonal man 'it' with trueimpersonal verbs denotes informality (Indrambarya 2011). Instances of the archaic use of the 3rd person pronoun thân $n_{1}$ 'he, she' in a legal document dated between 1874 and 1933 were found. Yet, this thân $n_{1}$ 'he, she' is referential. Such usage is found exclusively in Military Law, Civil Law and Commerce, and regulation for civilians. The word thân in legal language originally referred to the King who promulgated laws and regulations to signify his supreme power. Once the country became a constitutional monarchy, the word was no longer used in legal language. Therefore, thân in (27) is a third personal pronoun found exclusively in an old legal text.
(27)

$$
\begin{aligned}
& \text { Act 19. phûday pen thahăan } l \varepsilon \text { ? } \\
& \text { anyone be soldier and } \\
& \text { man bay ìat klîaklòm } \\
& \text { it dare persuade } \\
& \text { khon hây pen phûak } \\
& \text { person cause be group } \\
& \text { ráchasàttru thân wâa } \\
& \text { enemy they say } \\
& \text { Nom } \\
& + \text { rfrn } \\
& \text { thôot manthĭy tôy } \\
& \text { pardon it reach touch } \\
& \text { prahăantiiwîit ... } \\
& \text { death penalty }
\end{aligned}
$$

(Military Law 1934)

As illustrated in this section, the impersonal pronoun $\mathrm{man}_{2}$ 'it' is the most prevalent. The occurrence of impersonal pronouns is limited to everyday language and political language, with the highest frequency in everyday usage. Impersonal pronouns are not found to be associated with legal, academic and media language registers, which are mostly formal language. The next section discusses how each impersonal pronoun reflects social distance.

\section{Impersonal Pronouns and Social Distance}

This section discusses how the three impersonal pronouns exhibit different degrees of social distance. The three personal pronouns in Thai convey different characteristics when co-occurring with animate subjects. While man $_{1}$ 'it' conveys a derogative meaning, intimacy and colloquial speed, kháw $w_{2}$ 'he, she' is used to refer to people of equal or lower status. The personal pronoun thân $n_{2}$ 'he, 
she' is used to refer to a respected person and/or an acquaintance of high rank. Each of these intrinsic hierarchical values is carried over to their homophonous impersonal counterparts.

\section{The Impersonal Pronoun $\operatorname{man}_{2}$ 'it'}

The impersonal pronoun $\mathrm{man}_{2}$ 'it' which co-occurs with pseudo-impersonal verbs reflects social distance quite clearly. The pronoun $\mathrm{man}_{2}$ 'it' reflects alienation from the speaker and at the same time brings the speaker closer to listeners. In example (28), instead of calling herself phîi 'sister', the speaker prefers to lose her own self and uses $\mathrm{man}_{2}$ 'it' instead. In this way the speaker is able to share her own experience freely with others, no matter how bad it sounds, as if she is talking about someone else, not herself.

(28) man plia // phîi mây yàak yím //

it tired older not want smile

o mây yàak pay năy not want go where

man plia // man mòt recy it tired it use up energy 'I feel tired. I don't want to smile. I don't feel like it. I don't want to go anywhere. I am exhausted. I have used up all my energy.'

(daily conversation)

\section{The Impersonal Pronoun kháw $w_{3}$ 'they'}

The impersonal pronoun kháw 3 'they' refers to other people of equal status just like its personal counterpart. The impersonal pronoun kháw $w_{3}$ 'they' can be used to secure and support a speaker's voice and opinions. That is, listeners are urged to feel there are many other people who perform a similar action. The impersonal pronoun $k h a ́ w_{3}$ 'they' is used in example (29) to show that the idea of passing under an (artificial) elephant would be widely acceptable. Many people have done this. Therefore, it is not odd to do something similar. This pronoun kháw 3 'they' can refer to anyone out there who supports such an idea, and hence it is impersonal.

$$
\begin{aligned}
& \text { (29) } \boldsymbol{k h a ́}_{3} \text { wâa Ø lôst thósy } \\
& \text { they say pass abdomen } \\
& \text { țáay lécw cà? klôst yâay } \\
& \text { elephant then will give birth easy } \\
& \text { 'It is said that if (a pregnant woman) } \\
& \text { passes underneath an elephant, she } \\
& \text { will have a smooth delivery.' } \\
& \text { (daily conversation) }
\end{aligned}
$$

\section{The Impersonal Pronoun thân ${ }_{3}$ 'they'}

Since the personal pronoun thân $n_{3}$ 'they' normally refers to someone older or in a higher position, the word thân $n_{3}$ 'they' maintains this intrinsic semantic feature of being of high rank and reflects a certain distance from the addressee. A speaker could then manipulate the impersonal thân ${ }_{3}$ 'they' to gain more creditability with regard to the topic in focus, as in (23) repeated here as (30).

(30) thân ${ }_{3}$ hây Paw tônmayarâap they make take mimosa plant tônkrôpcakrawan maa laáy all purpose plant come wash náam saPàathàn pen fry water clean chop be shred tàak hây hêy khûa fay sun-dry till dry roast fire hây sùk rin námyaa make fully cooked pour medicine ráprathan thecn náamţaa eat instead of tea

'It is said that after rinsing mimosa and the all-purpose plants clean water, and then shredding, sun-drying and 
roasting till them cooked, one can drink the juice as a tea.'

(traditional recipe for making herbal medicine for curing diabetes)

Example (30) is a traditional recipe for curing diabetes. Since this recipe has earned its reputation by a word-of-mouth from generation to generation, it is not known exactly who initiated it. The writer then intentionally uses thân $n_{3}$ 'they' to convince readers that the far-fetched and less known recipe has been highly regarded as efficacious and that this herbal medicine might be worth a try.

As shown in this section, the three impersonal pronouns exhibit different degrees of social distance. Figure 2 captures how the three impersonal subjects reflect different degrees of social distance from listeners. While the impersonal pronoun $\mathrm{man}_{2}$ 'it' brings a speaker closest to a listener, the impersonal pronoun $t h a n_{3}$ 'they' pushes a listener furthest away.

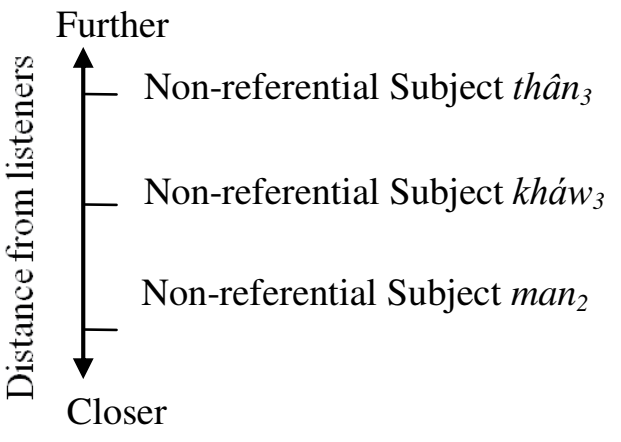

Figure 2: Relations between Impersonal Subjects and Social Distance

\section{Impersonal Pronouns and Language Power}

Social distance correlates closely with power over interlocutors. Hence, each impersonal subject reflects different degrees of power over listeners. By using thân $_{3}$ 'they', a speaker is able to motivate others to do as he/ she wishes by claiming the authority of wise elders while creating a certain gap of respect and high regard from listeners, as shown earlier in (30).

With the pronoun kháw 'they' in (29), a speaker could consolidate his/her power by informing listeners of what other people have said and indirectly motivating listeners to believe him/ her and to follow his/ her lead.

While the impersonal pronouns thân 'they' and kháw 3 'they' claim an authority of others directly, the impersonal pronoun man 'it' brings a speaker closer to a listener so that a speaker could familiarize him/ herself with and befriend a listener. Once the listener's trust has been gained, the speaker could further motivate him/ her. It is a more indirect way of expressing power. It is not surprising to find the use of impersonal $\mathrm{man}_{2}$ 'it' in political language, in addition to everyday language. In (31), the impersonal man 'it' co-occurs with the true-impersonal verb mii 'to exist' and makes the sentence informal. It is common for a politician to use the impersonal man 'it' with trueimpersonal verbs in his/ her speech because it brings politicians closer to their supporters.

(31) man mii khon sùan nìy thîi it exist person part one that kháw pay plùkradom wáy they go provoke lying 
'There are a group of people who have been provoked.'

(political speech)

Moreover, it is natural for politicians to familiarize themselves with their advocates. The presence of man 'it' in their speech with pseudo-impersonal verbs enables politicians to express and share their feelings and opinions with their supporters, as in (32).

$$
\begin{aligned}
& \text { man cèppùat thii raw tôy } \\
& \text { it pain that we must } \\
& \text { țótţay paasìi țaawbâan } \\
& \text { pay for tax villager } \\
& \text { hây kàp khon klùm nìy } \\
& \text { for with person group one } \\
& \text { 'It is painful that our taxes need to be } \\
& \text { spent to pay off debts made by for a } \\
& \text { group of people.' }
\end{aligned}
$$

(political speech)

Here, a politician brings him/herself closer to his advocates by sharing how painful it is for both citizens to pay debts made by a group of selfish people. Once the politician gains trust and amity, it is not difficult for a politician to induce further motivation and movement.

Figure 3 illustrates how Thai impersonal subjects reflect degrees of power over listeners with $t h a n_{3}$ 'they' being the most influential pronoun and $\mathrm{man}_{2}$ 'it' being the least influential.

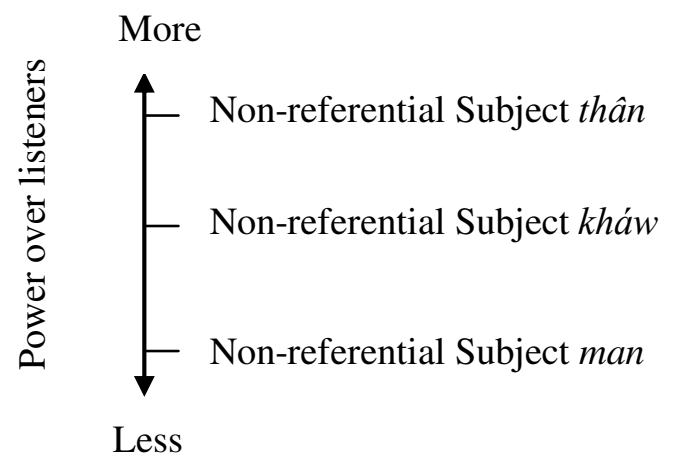

Figure 3: Relations between Impersonal Subjects and Language Power

\section{Conclusion}

The three Thai impersonal pronouns are found mainly in everyday language and political language. They are rarely found in legal language, academic language or language of news reports as well as magazine advertisements.

These impersonal pronouns exhibit different degrees of social distance and language power over listeners. It is claimed in this paper that by using the impersonal pronoun thân, a speaker creates the largest gap from a listener by appealing to the authority of past wisdom to induce listeners to do as he/ she wishes. By using the impersonal pronoun kháw, a speaker makes a certain gap away from a listener and searches for power of precedence or a claim on what other people have said or done, while then allows the listener to ponder whether to believe him/ her. Both thân and kháw are not commonly used and are exclusively found in everyday language.

The impersonal pronoun man 'it', on the other hand, not only makes sentences informal but also separates a speaker from his or her own self and brings closer 
connection with the listener. Use of this pronoun is offer a strategy for gaining the listener's trust, friendship and cooperation, a common tactic found in political language.

\section{References}

Angkhapanichkit, Janthima. 2010. The Grammatical Function of the Word man in Thai and speakers of Different Ages (in Thai). Paper Presented at the New Dimensions in Thai Grammatical Analysis. Kasetsart University, July 12- 13, 2010.

Creissel, Denis. No date. Impersonal Pronouns and Coreference : the case of French on. To appear in Manninen, S., K. Hietaam, E. Keiser \& V. Vihman (eds.). Passives and Impersonals in European Languages. Retrieved from http://www.deniscreissels.fr/public/ Creissels-ON.pdf

2011. Impersonal pronouns and coreference: two case studies. Journée sur les pronoms impersonnels. Workshop on impersonal pronouns. Paris, 20 Sept. 2011.

Hofherr, Cabredo. 2003. Arbitrary reading of $3 \mathrm{pl}$ pronominals. In M.Weisgerber (Ed.) Proceedings of the Conference" Sub7-Sinn und Bedeutung, 7th Annual Meeting of the Gesellschaft fur Semantik.' Arbeitspapier Nr. 114, FB Sprachwissenschaft, Konstanz University.
Indrambarya, Kitima. 1996. On Impersonal Verbs in Thai. PanAsiatic Linguistics: Proceedings of the Third International Symposium on Language and Linguistics. 505-521.

2011. On the Non-Referential Thai man 'it'. Paper presented at the $21^{\text {st }}$ Southeast Asian Linguistics Society, 11-13 May, 2011, Kasetsart University, Bangkok.

2012. On Impersonal Subjects in Thai." Paper presented at Paper presented at the $22^{\text {nd }}$ Southeast Asian Linguistics Society, 29 May -1 June, 2012, Agay, France.

Mathew, Peter. 1997. The Concise Oxford Dictionary of Linguistics. Oxford: Oxford University Press.

Phimsawat, On-Usa. 2011. The Syntax of Pro-drop in Thai. Doctoral Dissertation. New Castle University.

Sugiharto, Setiono. 2004. Reference, Anaphora, and Deixis: An overview. Junal Bahasa \& Sastra. Vol.4 No.2, September 2004: 134-145. 